DEPARTMENT OF THE INTERIOR

UNITED STATES GEOLOGICAL SURVEY

\title{
AEROMAGNETIC MAP OF MONTANA: IN COLOR
}

By Isidore Zietz, Francis P. Gilbert, and Stephen L. Snyder 